\title{
SADOMASOCHISTS UNSHACKLED?
}

\author{
IAN LEADER-ELLIOTT
}

\section{CONTENTS}

Jordan Moulds boldly argues in the primary article that sadists should enjoy extensive liberty under the law to pursue sexual fulfilment by inflicting pain or injury on consenting masochists. ${ }^{1}$ The liberty of the sadist would be constrained by a requirement of informed and competent consent by the masochist and by a further requirement that their activities take place in private, if they exceed the elastic limits of public tolerance for indecent spectacles. Those constraints aside, Moulds would recognize few limits on the sadist's licence to inflict harm. He suggests that informed consent might immunize a sadist from criminal liability for inflicting even a serious or disabling injury.

We disagree about sadomasochism. Moulds argues that Australian courts, and South Australian courts in particular, would not follow the authority of the House of Lords in $R v$ Brown $^{2}$ because the consensual infliction of pain and physical harm is now acceptable and may even possess some social value as recreation. If the activities that led to prosecution in that case are representative of sadomasochism, I would be dismayed to find that they have become acceptable and incredulous about the claim that they have social value. Even so, he and I do not seem so far apart: he is concerned to predict what courts will do, while I am concerned with a question of principle whether Australian courts should follow $R v$ Brown. I will argue they should not, unless constrained by statute. Moulds argues that they will not. These

Ian Leader-Elliott, LLB (Hons) (University of Melbourne), JD (University of Chicago), Adjunct Professor in Law, Law School, University of South Australia, Emeritus Fellow, University of Adelaide.

1 Jordan Moulds 'Is Society Still Shackled with the Chains of a 1993 England?: Consent, Sado-Masochism and $R v$ Brown' (this volume).

2 [1994] 1 AC 212. 
questions of prediction and principle have interesting consequences in the South Australian law of offences against the person.

The primary article deploys three arguments in support of an extension of liberty for sadists and masochists. (We should not assume that masochists who suffer harm are without criminal responsibility for the harm they suffer at the hands of their partner. $)^{3}$ The first argument is based on published surveys and other evidence of public tolerance for diversity in the sexual activities of consenting adults. Moulds draws on Diane Richardson's concept of 'sexual citizenship' in which rights to engage in particular forms of sexual conduct are elements in a larger complex or 'system of rights, which includes a concern with conduct, identity and relationship-based claims'. ${ }^{4}$ Sadomasochists might claim, in this way, a kind of citizenship right to the same recognition, acceptance and liberty of sexual conduct as individuals who identify as LGBT or heterosexual.

The second argument draws on a declaration in the Human Rights (Sexual Conduct) Act 1994 (Cth) that Australian legislatures may not arbitrarily interfere with the sexual conduct of consenting adults in private. ${ }^{5}$ This contention has been the subject of comprehensive consideration by Theodore Bennett ${ }^{6}$ and will not be discussed in this comment.

The third argument for acceptance of sadomasochistic practices is more original. South Australian statutory provisions dealing with offences of assault and causing personal harm depart in several interesting ways from corresponding legislation and common law in other Australian jurisdictions. Moulds contends that the provisions, which were introduced in $2005,{ }^{7}$ go beyond the Human Rights (Sexual Conduct) Act 1994 in their recognition and protection of sadomasochists from criminal sanctions. The South Australian reforms, which were based on the Model Criminal Code, ${ }^{8}$ were intended to

3 On the potential liability of the masochist, see Gabriel Hallevy, 'Victim's Complicity in Criminal Law’ (2006) 2 International Journal of Punishment and Sentencing 72.

4 'Constructing Sexual Citizenship: Theorizing Sexual Rights' (2000) 20 Critical Social Policy 105, 128.

5 Section 4(1): 'Sexual conduct involving only consenting adults acting in private is not to be subject to, by or under any law of the Commonwealth, a State or a Territory, to any arbitrary interference with privacy within the meaning of Article 17 of the International Covenant on Civil and Political Rights.'

6 Theodore Bennett, 'Sadomasochism under the Human Rights (Sexual Conduct) Act 1994' (2013) 22 Sydney Law Review 541.

$7 \quad$ Statutes Amendment and Repeal (Aggravated Offences) Act 2005 (SA).

8 A current version of the Code can be found at: Model Criminal Code, $1^{\text {st }}$ edition, 28 May 2009, Parliamentary Counsel's Committee 
eliminate common law clutter and 'irrational distinctions' inherited from English statutory law of offences against the person. ${ }^{9}$ The reforms provide a usefully suggestive context for the primary article's consideration of the larger implications of the concept of autonomous sexual citizenship. I do not agree, however, that the South Australian reforms have the expansive effect which Moulds claims for them.

The South Australian Criminal Law Consolidation Act 1935 ('CLCA') distinguishes between the offence of assault and the more serious Division 7A offences of causing harm intentionally or recklessly. Assault, which occupies its own Division 7 in the Act, was a late inclusion in the 2005 reform Bill. The original intention seems to have been to eliminate assault entirely, on the ground that the common law concept was incoherent and unsalvageable. The offences of causing harm, which are not constrained by the technical limits of assault, ${ }^{10}$ were supposed to take its place. After some hesitation, assault was retained because the Division $7 \mathrm{~A}$ offences do not extend to assaults that merely violate rights or injure dignity. A lesser offence of assault is, moreover, an indispensable inducement in plea bargaining.

Moulds bases his argument for an extended liberty for sadomasochists on what might seem, on first impression, to be a generous statutory defence of consent in s 22(3) of the CLCA, which applies to the Division 7A offences of causing harm. The defence has no application, however, to the Division 7 offence of assault in either its basic or aggravated form of assault causing harm. ${ }^{11}$ I will return to the problem of assault at the end of this comment.

Consent can bar conviction for any of the seven Division 7A offences of causing or endangering 'harm', an expression which is defined in terms of broad inclusiveness, extending to mental or physical harms, whether

$<$ http://www.pcc.gov.au/uniform/crime\%20(composite-2007)-website.pdf>.

9 Model Criminal Code, 'Chapter 5 Non Fatal Offences Against the Person', Report September 1998, 13 and generally, the Commentary 13-47.

10 Assault, in both its common law and $C L C A$ formulation in s 20 requires proof of an actual or threatened physical contact between offender and victim without consent. The concept will have no application in many cases of harm done by poisoning, traps and spring guns, infection with a disease, psychological hurt, and so on.

11 Criminal Law Consolidation Act 1935 (SA), s 20(4). The basic offence is punishable with a maximum penalty of two years imprisonment, which rises to three years if 'harm', which is not defined, results from the assault. Liability is absolute with respect to the aggravating element of harm: see the statutory 'Note' appended to the provision and Coulter $v$ Queen (1988) 164 CLR 350. 
permanent or temporary. Pain, of itself, amounts to 'harm' ${ }^{12}$ Consent can be a defence even in cases where the defendant is charged with the offence of intentionally causing 'serious harm'. The potential breadth of the defence will be apparent from the definition of 'serious harm': which is an injury which endangers life, results in serious and protracted impairment of a physical or mental function or causes serious disfigurement to the victim. ${ }^{13}$ The defence is qualified, however. Consent will not excuse the infliction of harm of any degree, whether serious or not, unless the 'nature of the harm and the purpose for which is it is inflicted fall within limits that are generally accepted in the community. ${ }^{14}$

Moulds contends that the infliction of harms that are a concomitant of the 'sexual citizenship' of sadists and masochists is now tolerable and within the limits of general acceptance. In trials for any of the offences of causing harm or serious harm a defendant who adduces credible evidence of consent by their alleged victim would be entitled to call on the prosecution to prove that the nature of the harm or the purpose for which it was inflicted went beyond the limits of community tolerance.

I have three reflections to offer on this challenging exploration of criminal liability for consensual harms. The first has to do with the absence of principle in the South Australian legislative developments. The second casts doubt on the cogency of the primary article's enquiries into the social utility or benefit of sadomasochism when the potential criminal liability of the sadist for causing harm is in issue. The third draws attention to another peculiarity of South Australian criminal law, a peculiarity that has particular significance in discussion of consensual harms. The CLCA offences against the person do not include an offence of causing harm by negligence.

\section{PRINCIPLED LiBERALISM OR SOCIAL UTILITY?}

The primary article's concerns are predictive rather than principled. Moulds asks what South Australian courts might be expected to do, two decades after $R v$ Brown, when the CLCA requires consideration of the question whether a consensual harm falls within limits 'generally accepted' by the community.

12 Criminal Law Consolidation Act 1935 (SA), s 21. Since its application is confined to Division 7A of the Act, the definition of harm, like the other definitions in s 21, has no application to Division 7 Assault.

13 Ibid s 21. The definition was adopted from the Model Penal Code (American Law Institute, Proposed Official Draft, 1962) s 210.0(3).

$14 \quad$ Ibid s 22(3). 
Some cases are easy. When Bernd Brandes agreed to share his grisly repast with Armin Miewes, the German cannibal, there can be no doubt that Brandes' consent would not excuse the mutilation inflicted on him by Miewes. ${ }^{15}$ The injury was serious within the meaning of the CLCA and it was shocking beyond any conceivable application of the criterion of general community acceptance. It is very far from clear, however, that the same test would benefit the defendants in $R v$ Brown though the injuries inflicted on the masochists were not 'serious'. Life was not endangered; the masochists were not disfigured and none of their physical or mental functions were significantly impaired. No-one was offended by a public display of the participants' peculiar pleasures. Though the harm was not serious, it does not seem at all likely that a jury would consider the repellent activities of the defendants to be generally acceptable in the South Australian community.

The CLCA requirement of community acceptance is indefensible in principle. It is a central tenet of the rule of law that conduct that is prohibited on pain of criminal punishment should be clearly defined in advance. Punishment for crime should not be determined by a retrospective expression of community opinion or 'acceptance'. The Indian Penal Code, enacted in 1860, provides an instructive comparison with the South Australian legislation: 'Free and intelligent consent' to suffer a harm is a general defence unless the harm was intended to cause death or 'grievous hurt'. ${ }^{16}$ The defence of consent is not diluted by an additional requirement of general community acceptance. Thomas Macaulay, whose draft Code of 1837, provided the basis for the Indian Penal Code ${ }^{17}$ provided a classically liberal justification of the defence of consent. In general, he argued, people are the best judges of their own interests. Legislatures cannot restrain individuals who have reached maturity 'from destroying their own property, their own health, their own comfort, without restraining them from an infinite number of salutary or innocent actions. ${ }^{18}$ However, Macaulay set a limit. Consent could not excuse an intentional homicide: 'by prohibiting a man from intentionally causing the death of another, we prohibit nothing which we think it desirable to

15 A brief account can be found in the Cornell Law School, Legal Information Institute, 'Cannibalism', <https://www.law.cornell.edu/wex/cannibalism>. The reference in the text above refers to the initial, consensual transaction between Miewes and Brandes, before Brandes was killed. See also Hallevy, above n 3.

16 Indian Penal Code 1861, s 87. Grievous hurt is defined with some particularity in s 320 , in terms generally congruent with the definition of 'serious harm' in s 20 Criminal Law Consolidation Act 1935 (SA).

17 The draft and Macaulay's accompanying 'Notes' can be found in A Copy of the Penal Code, prepared by the Indian Law Commissioners (Stephen Austin, 1851).

18 Ibid, 'Note B - On the Chapter of General Exceptions', 129, 130. 
tolerate'. ${ }^{19}$ Modern Indian law draws the line a little more conservatively: the defence has no application if the person intended to kill or inflict 'grievous hurt'. 20

The contrast between the autonomy permitted to consenting adults under the Indian Penal Code and the paternalism of the CLCA is obvious. ${ }^{21}$ The South Australian requirement that consensual harms fall within limits generally accepted in the community prompted the primary article's search for some redeeming social benefit or utility in the practices of sadomasochists. General acceptance is a fragile foundation for tolerance of diversity. The sadomasochistic antics of the defendants in $R v$ Brown were of no social value except, perhaps, as bizarre examples of conduct to be avoided. ${ }^{22}$ The same can be said of religious mortifications, ${ }^{23}$ bizarre rites of exorcism by adherents of crank religions ${ }^{24}$ and various other consensual harms that continue to generate legal controversy. The Indian Penal Code imposes a far more principled limit on the infliction of criminal punishment for consensual harms. It extends tolerance to consensual harms that do not meet with general acceptance by the community, so long as the active partner does not intend to cause grievous hurt or to kill their victim.

Though South Australian courts must make the best they can of the defence of consent in s 22(3) of the CLCA, with its requirement of community acceptance, other Australasian jurisdictions do not share this particular impediment when determining the limits of consent. The most exhaustive exploration of common law limits to date is the New Zealand Court of Appeal decision in $R v$ Lee $^{25}$ a case of exorcism that ended in tragedy. In summary, the Court held that consent is a general, common law defence so long as grievous bodily harm was not intended or known to be likely. If

19 Ibid 131

20 Ibid. The general defence is supplemented by defences of particular application in cases of medical necessity and the like.

${ }^{21}$ For a useful review of recent arguments against legislative paternalism, see Heidi Hurd, 'Paternalism on Pain of Punishment' (2009) 28 Criminal Justice Ethics 49.

22 Ibid 68-69: '[V]arious forms of sadomasochistic sexual practices, adult pornography, and so forth - may indeed be a necessary means of educating people about the moral and personal perils of such behaviour'.

23 Jo Pearson, 'Embracing the Lash: Pain and Ritual as Spiritual Tools' in Religion and the Body, Tore Ahlbäck (ed), (Donner Institute for Research in Religious and Cultural History, 2011) 351. Pearson's paper can also be accessed at: $<$ https://www.academia.edu/5878883/Embracing_the_Lash_Pain_and_Ritual_as_Spiritual_ Experience_>.

$24 \quad R v$ Lee [2006] 3 NZLR 42.

25 Ibid. 
grievous bodily harm was intended or known to be likely, consent may still be available as a defence unless the court determines that reasons of public policy outweigh the right to personal autonomy. ${ }^{26}$ When the activity is consensual, the question whether the harm inflicted is 'acceptable' to the community or of social value cannot arise, unless intentional or reckless infliction of grievous bodily harm is in issue. ${ }^{27}$ This is close to the Indian Penal Code provision, which sets the limit at intentional infliction of 'grievous hurt'.

\section{Negligent HARMS AND STATUTORY ASSAUltS}

There is another peculiarity of the South Australian legislation which is pertinent to the law of consensual harms. Alone among Australian jurisdictions, South Australia has not enacted a general prohibition against causing harm by criminal negligence. ${ }^{28}$ The offences against the person in the Victorian Crimes Act 1958, which are very similar in other respects to their South Australian counterparts, provide an instructive comparison. Section 24 makes it an offence to cause 'serious injury' by negligent act or omission. ${ }^{29}$ The offence complements manslaughter by gross negligence. These offences of negligence are likely to find application when consensual harms cause unexpected death or injury.

Medical procedures aside, consensual harms are rarely intended or known by the participants to be likely to cause death or harm that is 'serious'. 30 Criminal prosecution arising from consensual harms is most likely when the participants' activity comes to attention because something has gone wrong,

26 The Court allowed one interesting exception to the general defence of consent to lesser harms. Injuries intentionally inflicted in fights are not excused by consent, unless they occur in organized matches, conducted with a referee: $R v$ Lee [2006] 3 NZLR 42, 116 [299] (Glazebrook J for the Court).

27 Ibid 119 [311]-[318]. But see Neal v The Queen (2011) 32 VR 454, 474 [68], 475 [73], on consensual transmission of HIV - a serious harm - holding that intentional as distinct from a reckless transmission of the infection to a willing partner could not be excused.

28 But see the peculiar provision in the Criminal Law Consolidation Act 1935 (SA), s 268(5), which imposes criminal liability for causing serious injury by negligence, if the offender was intoxicated.

29 Crimes Act 1958 (Vic), Division 1, Offences against the person, s 24 Negligently causing serious injury.

30 But see Michael Elliston, 'Ex Doctor Faces Life for Botched Fetish Amputation' The Guardian (online), 7 October 1999,

< http://www.theguardian.com/world/1999/oct/07/michaelellison>. 
with unexpectedly serious consequences. Erotic asphyxiation, ${ }^{31}$ cosmetic wounds, ${ }^{32}$ perilous exorcisms ${ }^{33}$ and mutual administration of dangerous drugs $^{34}$ can all result in serious harm or death. When serious harm or death is unexpected, consent can excuse the act which caused the harm. There remains, however, the possibility of liability for negligent homicide or injury resulting from a breach of the duty of care owed by the active partner to their passive victim. Consent is no answer to an accusation of negligence when the activity in question is dangerous and the active participant was incompetent or careless in its execution. South Australia is exceptional in its failure to make provision for negligent infliction of serious injury.

There is a final and paradoxical note to add to this exploration of the peculiarities of South Australian law. Sadomasochists and others of their ilk may be charged with assault causing harm under Division 7 of the $C L C A$, rather than one of the more serious Division 7A offences of causing harm. If that were to happen, the question whether consent excuses the assault will depend on the common law, for the statutory defence in Division 7A has no application to Division 7 assault. The common law defence of consent to assault causing harm may prove to be more generous than $\mathrm{s} 22(3)$ which is constrained within 'limits that are generally accepted in the community'.

$31 \quad$ See $R v$ Stein (2007) 18 VR 376 for discussion of Australian case law. Erotic asphyxiation has its own extensive literature, both prurient and scholarly. For an apologia, see Ingrid Olson, 'Asking for it: Erotic Asphyxiation and the Limitations of Sexual Consent' (2012) 4 Jindal Global Law Review 171. On the dangers of recreational asphyxiation see, among many other sources, Robin L Tobin et al, 'Unintentional Strangulation Deaths from the "Choking Game" Among Youths Aged 6-19 - United States, 1995-2007' (2008) 39 Journal of Safety Research 445, (a US study of prevalence and risks among children and young adults of the practice of self-strangulation or strangulation by another person to achieve a brief euphoric state caused by cerebral hypoxia). Deliberate homicide or infliction of injury is not infrequently masked by claims of consensual erotic asphyxiation: see Heather Douglas and Robin Fitzgerald, 'Strangling, Domestic Violence and the Legal Response' (2014) 36 Sydney Law Review 231.

$32 \quad R v$ Wilson [1996] 2 Crim App R 241. See generally, Amanda J Watkins, 'Score and Pierce: Crimes of Fashion? Body Alteration and Consent to Assault' (1998) 28 Victoria University of Wellington Law Review 371.

$33 \quad R v$ Lee [2006] 3 NZLR 42.

$34 \quad$ Neal $v$ The Queen (2011) 32 VR 454. 